\title{
KEABSAHAN PENJAMINAN HAK MILIK ATAS TANAH YANG DIDASARKAN PADA AKTA DI BAWAH TANGAN (STUDI KASUS PUTUSAN NOMOR 53/PDT.G/2017/PN.SGN).
}

\author{
Akbar Rahadianto \\ (Mahasiswa Program S1 Fakultas Hukum Universitas Tarumanagara) \\ (E-mail : $\underline{\text { rahadianto.akbar@gmail.com) }}$
}

\section{Endang Pandamdari}

(Corresponding Author)

Dosen tidak tetap Fakultas Hukum Universitas Tarumanagara, Meraih

Sarjana Hukum (S.H) dari Fakultas Hukum Universitas Indonesia (1983),

Pendidikan Spesialis Notariat dari Universitas Indonesia (1993), Magister

Hukum (M.H) dari Fakultas Hukum Universitas Indonesia (1996), Doktor

Ilmu Hukum (Dr) dari Fakultas Hukum Universitas Trisakti (2011).

(E-mail : Epandamdari@yahoo.com)

\begin{abstract}
Land rights guarantee is a guarantee made by the debtor to the creditor which generally aims to obtain a loan in the form of money for the debtor and repayment of debt to the creditor. In the case of guaranteeing land rights, the procedure has been regulated in the Underwriting Rights on land along with land-related objects act. In this act, it is explained that in the case of guaranteeing land rights, it must be made in an authentic deed named deed of mortgage. But in this case the debtor guarantees ownership rights of the land to the creditor with only deed under hand, not with the deed of mortgage. Is the guarantee still valid? and how about the executorial power? In this study the author uses a case approach and legislative approach. It can be concluded that the guarantee of ownership rights on land based on the deed under the hand is valid because it has fulfilled the elements of Article 1320 of the Civil Code concerning the legal requirements of the agreement. Then for the execution strength, it can be done, but it will be very difficult because it requires a court order to execute the collateral object. The suggestion from the author is that in guaranteeing the rights to the land, it must be charged the Deed of mortgage, so that if there is a default, the execution of the guarantee object is easy and does not take a long time.
\end{abstract}

Keywords : Land rights guarantee, deed of mortgage, deed under hand. 


\section{PENDAHULUAN}

\section{A. Latar Belakang}

Indonesia merupakan negara yang berasaskan Pancasila dan berlandaskan pada Undang-Undang Dasar Negara Republik Indonesia Tahun 1945 (UUDNRI 1945). Dalam hal kebutuhan tanah, konstitusi Indonesia telah menjelaskannya di dalam Pasal 33 ayat (3) Undang-Undang Dasar Negara Republik Indonesia khususnya dalam bidang agraria yang berbunyi :

"Bumi dan air dan kekayaan alam yang terkandung di dalamnya dikuasai oleh negara dan dipergunakan untuk sebesar-besarnya kemakmuran rakyat."

Berdasarkan uraian Pasal 33 ayat (3) UUDNRI 1945 tersebut dapat kita ketahui bahwa tanah di Indonesia dikuasai oleh negara dan diberi landasan hukum oleh negara guna kemakmuran seluruh rakyat Indonesia. Hukum yang mengatur pertanahan ialah dinamakan hukum agraria. Suatu hukum yang mengatur hubungan hukum antara subjek hukum dalam bidang agraria disebut sebagai hukum agraria. Dalam hukum agraria terdapat banyak norma hukum yang mengatur hubungan-hubungan antar subjek hukum agraria. Hukum Agraria merupakan kumpulan hukum yang mengatur pemanfaatan, penggunaan juga penguasaan Sumber Daya Alam (SDA). ${ }^{2}$ Salah satu aspek dalam hukum agraria adalah tanah. Kita perlu memberikan batasan dalam penggunaan tanah agar tanah tersebut dapat digunakan untuk kepentingan hidup bagi makhluk hidup lainnya. Maka dari itu tanah perlu dibatasi dalam hal penggunaannya. Dalam hukum tanah kata sebutan "tanah" dipakai dalam arti yaitu permukaan bumi, sebagai suatu pengertian yang telah diberi batasan resmi oleh Undang-Undang Nomor 5 Tahun 1960 tentang Peraturan Dasar Pokok-Pokok Agraria (UUPA). Tanah dicirikan sebagai suatu benda yang tak bergerak. Benda tak bergerak adalah benda yang sifatnya dan karena suatu aturan yang mengaturnya dinyatakan bahwa benda tersebut tak bergerak. Dalam Pasal 4 UUPA dinyatakan, hak menguasai dari

\footnotetext{
${ }^{1}$ Indonesia, Undang-Undang Dasar Negara Republik Indonesia tahun 1945, Pasal 33 ayat (3)

${ }^{2}$ Sahnan, Hukum Agraria Indonesia, Cetakan ke-1. (Malang : Setara, 2016), hal. 7.
} 
negara ditentukan berbagai macam hak atas permukaan bumi, yang disebut tanah, yang dapat diberikan kepada dan dipunyai oleh orang-orang. Dengan demikian jelaslah, bahwa tanah dalam pengertian hukum atau peraturan perundangundangan yang berlaku adalah permukaan bumi sebagaimana dijelaskan dalam Pasal 4 ayat (1) UUPA, sedangkan hak atas permukaan bumi yang dimana permukaan bumi tersebut dapat diukur dengan satuan panjang lebar yang diakui masyarakat secara umum disebut sebagai hak atas tanah. ${ }^{3}$ Menurut Kamus Besar Bahasa Indonesia tanah adalah :

1. Permukaan bumi atau lapisan bumi yang di atas sekali;

2. Keadaan bumi di suatu tempat;

3. Permukaan bumi yang diberi batas;

4. Bahan-bahan dari bumi, bumi sebagai bahan sesuatu (pasir, cadas, napal dan sebagainya). ${ }^{4}$

Dalam hukum tanah nasional dikenal hak-hak perorangan atas tanah yang dapat berupa hak atas tanah dan hak jaminan atas tanah. Pengertian Jaminan atas tanah atau hak tanggungan adalah menurut Pasal 1 angka 1 Undang-Undang Nomor 4 Tahun 1996 tentang Hak Tanggungan atas Tanah Beserta Benda-Benda yang Berkaitan dengan Tanah (UUHT) adalah:

"Hak jaminan yang dibebankan pada hak atas tanah sebagaimana dimaksud di dalam Undang-Undang No.5 tahun 1960 tentang Peraturan Dasar Pokok-Pokok Agraria berikut atau tidak berikut benda-benda lain yang merupakan satu kesatuan dengan tanah tersebut untuk pelunasan hutang tertentu, yang memberikan kedudukan yang diutamakan kepada kreditur tertentu terhadap ,kreditur-kreditur lainnya."

Boedi Harsono mengartikan hak tanggungan ialah penguasaan hak atas tanah, dimana dalam hak tanggungan kreditur memiliki kekuasaan atas tanah dan bendabenda yang berkaitan dengan tanah lainnya yang dijaminkan kepadanya oleh

\footnotetext{
${ }^{3}$ Boedi Harsono, Hukum Agraria Indonesia Sejarah Pembentukan Undang-Undang Pokok Agraria, Isi dan Pelaksanaannya, Cetakan ke-8. (Jakarta: Djambatan, 1999), hal. 19.

${ }^{4}$ Kamus Besar Bahasa Indonesia (KBBI).

5 Indonesia, Undang-Undang No 4 Tahun 1996 tentang Hak Tanggungan Atas Tanah beserta Benda-Benda yang berkaitan Dengan Tanah (Lembaran Negara Republik Indonesia Tahun 1996 Nomor 42, Tambahan Lembaran Negara Republik Indonesia Nomor 3632), Pasal 1 angka 1.
} 
debitur. Tetapi tanah dan benda-benda terkait dengan tanah tersebut bukan untuk dimiliki secara pribadi, tetapi dijual untuk pelunasan hutang debitur yang wanprestasi atau cedera janji tersebut. ${ }^{6}$ Hak Tanggungan adalah salah satu dari jaminan hutang bersifat kebendaan yang dimana objek dari hak tanggungan adalah hak-hak atas tanah dan/atau benda-benda yang berkaitan dengan tanah yang diatur di dalam UUPA. ${ }^{7}$ Pengertian lain dari Hak Tanggungan ialah hak yang diberikan oleh undang-undang kepada seorang kreditur untuk didahulukan dari kredtitur-kreditur lain guna memperoleh pelunasan guna memperoleh pelunasan utang atas seorang debitur dari hasil penjualan agunan tertentu yang pada agunan tersebut hak tanggungan dibebankan berdasarkan suatu perjanjian suatu hak tanggungan antara kreditur dan pemilik agunan. ${ }^{8}$ Tata cara untuk pembebanan atau pemberian hak tanggungan terhadap objek hak tanggungan yaitu tanah dan/atau beserta benda-benda yang ada diatas tanah tersebut telah dijelaskan di dalam Pasal 10 ayat (1) dan ayat (2) UUHT, yang berbunyi sebagai berikut :

"Pemberian Hak Tanggungan didahului dengan janji untuk memberikan hak tanggungan sebagai jaminan pelunasan hutang tertentu, yang dituangkan didalam dan merupakan bagian tak terpisahkan dari perjanjian hutang-piutang yang bersangkutan atau perjanjian lainnya yang menimbulkan hutang tersebut."

"Pemberian hak tanggungan dilakukan dengan pembuatan Akta Pemberian Hak Tanggungan oleh Pejabat Pembuat Akta Tanah (PPAT) sesuai dengan peraturan perundang-undangan yang berlaku. ${ }^{9,}$

Jaminan hutang adalah keyakinan atau kepercayaan yang diberikan oleh debitur berupa benda-benda yang dijaminkan kepada kreditur atas pembayaran

\footnotetext{
${ }^{6}$ Boedi Harsono, Op.Cit., hal. 97.

7 Kartini Muljadi dan Gunawan Widjaja, Seri Hukum Harta Kekayaan Hak Tanggungan, Cetakan ke-2. (Jakarta: Prenada, 2006), hal. 13.

${ }^{8}$ Elips, Seri Dasar Hukum Ekonomi 4: Hukum Jaminan Indonesia, Cetakan ke-1. (Jakarta : Proyek ELIPS, 1998), hal. 221.

9 Indonesia, Undang-Undang No 4 Tahun 1996 tentang Hak Tanggungan Atas Tanah beserta Benda-Benda yang berkaitan Dengan Tanah (Lembaran Negara Republik Indonesia Tahun 1996 Nomor 42, Tambahan Lembaran Negara Republik Indonesia Nomor 3632), Op.Cit., Pasal 10 ayat (1) dan ayat (2)
} 
hutang-hutang yang telah diberikan oleh kreditur kepada debitur bahwa pelunasan hutang-hutang tersebut harus dilakukan sesuai dengan yang telah diperjanjikan dalam perjanjian hutang yang dibuat, Hal ini terjadi karena perjanjian tersebut bersifat assesoir terhadap perjanjian utamanya. ${ }^{10}$ Dalam kasus ini benda yang dijaminkan adalah tanah. Hak-hak atas tanah yang dapat dijaminkan ada 5 (lima) jenis hak, yaitu:

1. Hak Milik;

2. Hak Guna Usaha;

3. Hak Guna Bangunan; ${ }^{11}$

4. Hak Pakai Atas Tanah Negara;

5. Hak Milik Atas Satuan Rumah Susun. ${ }^{12}$

Dalam menjaminkan hak atas tanah, mekanisme pemberian hak tanggungannya sebagaimana dijelaskan dan diatur Pasal 10 ayat (1) UUHT pertama-tama harus dimulai dengan janji untuk memberikan hak tanggungan yang dilakukan untuk jaminan pelunasan hutang tertentu, yang mana hal ini merupakan bagian tidak terpisahkan dari perjanjian hutang piutang yang bersangkutan. Lalu menurut Pasal 10 ayat (2) Akta Pemberian Hak Tanggungan (APHT) harus dan wajib untuk dibuat. Pembuatan APHT tersebut dilakukan dihadapan pejabat umum yang berwenang, dalam hal ini adalah Pejabat Pembuat Akta Tanah (PPAT). Hal-hal tersebut dilakukan untuk pemberian atau pembebanan hak tanggungan terhadap tanah yang menjadi objek dari hak tanggungan dalam suatu perjanjian tertentu.

Dalam kasus yang diangkat, dalam penjaminan sertifikat hak milik atas tanahnya ialah dilakukan dengan tanpa akta autentik atau tidak dibebankan (APHT), melainkan penjaminan sertfikat hak milik atas tanahnya hanya berdasarkan perjanjian atau akta di bawah tangan yang mana tidak sesuai dengan prosedur yang telah ditetapkan oleh peraturan perundang-undangan yang berlaku,

\footnotetext{
${ }^{10}$ Munir Fuady, Hukum Jaminan Hutang, Cetakan ke-1. (Jakarta: Erlangga, 2013), hal. 8.

${ }^{11}$ Indonesia, Undang-Undang No 4 Tahun 1996 tentang Hak Tanggungan Atas Tanah beserta Benda-Benda yang berkaitan Dengan Tanah (Lembaran Negara Republik Indonesia Tahun 1996 Nomor 42, Tambahan Lembaran Negara Republik Indonesia Nomor 3632), Op.Cit., Pasal 4 ayat (1)

${ }^{12}$ Boedi Harsono, Op.Cit., hal. 426.
} 
yaitu di dalam UUHT. Fakta-fakta di lapangan banyak terjadi hal semacam ini, yaitu dimana pemberi jaminan sertifikat (debitor) menjaminkan sertifikat hak atas tanahnya baik hak milik, hak guna usaha, hak guna bangunan maupun hak pakai kepada penerima jaminan sertifikat hak atas tanah (kreditor) hanya berdasarkan perjanjian atau akta di bawah tangan.

Kasus ini terjadi di daerah Kabupaten Sragen, Jawa Tengah. Awal mula kasus ini, seorang bernama Amin Hamidi Hasanudin yang dalam kasus ini sebagai penggugat, melakukan perjanjian hutang piutang dengan Suyadi sebagai tergugat pada tanggal 24 Oktober 2015. Amin meminjamkan uang kepada Suyadi sebesar Rp200.000.000 (dua ratus juta rupiah) dan menjaminkan tanah sawahnya sebagai jaminan hutang, berikut tanah sawah tersebut yang dijaminkan :

1. Tanah sawah yang berdiri diatas sertifikat Hak Milik (SHM) N0.876, terletak di desa Gawan, Kecamatan Tanon, Kabupaten Sragen, atas nama tergugat, dengan batas-batas :

a. Sebelah Utara : Jalan

b. Sebelah Selatan : sawah milik Bapak Suyadi

c. Sebelah Barat : sawah milik Bapak Suyadi

d. Sebelah Timur : sawah milik Bapak Suyadi

2. Tanah Sawah yang berdiri diatas Sertifikat Hak Milik (SHM) No.877, terletak di Desa Gawan, Kecamatan Tanon, Kabupaten Sragen, atas nama tergugat, dengan batas-batas :

a. Sebelah Utara : Jalan

b. Sebelah Selatan : sawah milik Bapak Suyadi

c. Sebelah Barat : Saluran Air/Irigasi

d. Sebelah Timur ; sawah milik Bapak Suyadi

Dalam perjanjian hutang piutang antara Amin dengan Suyadi tersebut, yang dibuat dengan akta di bawah tangan, disepakati apabila terjadi wanprestasi atau dalam hal ini Suyadi tidak melaksanakan kewajiban mengembalikan hutang sampai batas waktu akhir Desember 2015, Amin bisa memproses secara hukum (memproses jaminan) dan pihak kedua (Suyadi) sanggup diproses, atau dengan 
kata lain jaminan yang berupa bidang sawah yang sertifikat hak milik atas nama Suyadi menjadi milik Amin. Berikut isi dari perjanjian tersebut :

1. Pihak pertama yaitu Amin Hamidi memberi hutang atau pinjaman uang kepada pihak kedua yaitu Suyadi sebesar Rp200.000.000 (dua ratus juta rupiah).

2. Pihak kedua atau Suyadi sanggup mengembalikan akhir bulan Desember 2015, dengan dengan dua jaminan Sertifikat Hak Milik (SHM) nomor 876 dan Sertifikat Hak Milik (SHM) nomor 877 yang masing-masing atas nama debitur. Apabila akhir bulan Desember 2015 Suyadi belum dapat mengembalikan maka pihak pertama yaitu Amin Hamidi dapat memproses secara hukum dan pihak kedua yaitu Sayudi sanggup diproses.

Pada akhirnya Suyadi selaku debitur tidak memenuhi kewajibannya, sehingga

Amin Hamidi Hasanudin selaku kreditur mengajukan gugatan di Pengadilan Negeri Sragen.

\section{B. Perumusan Masalah}

Berdasarkan hal-hal yang telah diuraikan diatas permasalahan yang diangkat dalam penulisan ilmiah ini adalah :

1. Bagaimana keabsahan penjaminan hak milik atas tanah kepunyaan bapak Suyadi tersebut permasalahan ?

2. Bagaimana kekuatan eksekutorialnya apabila penjamiannya hanya dilakukan berdasarkan pada akta di bawah tangan?

\section{Metode Penelitian}

\section{Jenis Penelitian}

Jenis penelitian yang digunakan di dalam penelitian ini adalah penelitian hukum normatif. Metode penelitian hukum normatif adalah metode penelitian yang didasarkan pada sumber-sumber kepustakaan, dengan kajian-kajian atau bahan-bahan pustaka yang tersedia. ${ }^{13}$ Penelitian hukum normatif adalah

13 Soerjono Soekanto, Penelitian Hukum Normatif Suatu Tinjauan Singkat, Cetakan ke-7 (Jakarta: Rajawali Pers, 2003), hal. 14. 
penelitian hukum yang dalam kegiatannya berkutat pada penjelasan dan caracara yang efekif agar bagaimana norma hukum dapat ditegakkan. ${ }^{14}$

\section{Jenis dan Teknik Pengumpulan data}

Jenis data yang digunakan adalah data sekunder. Data sekunder atau data kepustakaan atau dikenal dengan bahan hukum, dikelompokkan ke dalam bahanbahan hukum yang berjumlah 3 (tiga) jenis, yaitu yang terdiri dari bahan hukum primer, bahan hukum sekunder dan bahan hukum tersier. ${ }^{15}$

Teknik pengumpulan data yang dilakukan adalah dengan teknik pengumpulan data berdasarkan pada studi terhadap berbagai macam bahanbahan hukum yang disebut juga sebagai studi pustaka. Dalam studi pustaka ini terdapat 3 (tiga) bahan hukum yang menjadi bahan studi pustaka yaitu, bahan hukum primer, sekunder dan tersier. ${ }^{16}$ Tetapi, dalam penelitian hukum ini, akan lebih difokuskan pada bahan hukum primer dan sekunder.

\section{Pendekatan Penelitian}

Pendekatan penelitian yang digunakan adalah pendekatan kasus dan pendekatan undang-undang. Pendekatan kasus adalah pendekatan yang metodenya dilakukan dengan cara penelahaan terhadap permasalahanpermasalahan atau opini-opini yang sedang berkembang terkait dengan isu hukum yang sedang dihadapi. Sedangkan pendekatan undang-undang adalah pendekatan yang digunakan untuk menemukan undang-undang yang pas dalam permasalahan yang sedang diteliti, serta untuk menjawab permasalahan yang belum terjawab oleh undang-undang yang telah tersedia.

\section{Spesifikasi Penelitian}

Spesifikasi penelitian yang digunakan adalah spesifikasi yang bersifat preskriptif dan evaluatif, yaitu untuk memberikan argumentasi terhadap

\footnotetext{
14 I Made Pasek DIantha, Metodologi Penelitian Hukum Normatif Dalam Teori Justifikasi Hukum, Cetakan ke-1, (Jakarta: Prenada, 2016), hal. 84.

15 Mukti Fajar dan Yulianto Achmad, Dualisme Penelitian Hukum Normatif dan Empiris, Cetakan ke-1, (Yogyakarta: Pustaka Pelajar, 2010),., hal. 157.

${ }^{16}$ Ibid., hal. 160.
} 
penelitian yang sudah dilakukan dan memberikan justifikasi atau penilaian terhadap hasil penelitian.

\section{Teknik Analisis Data}

Teknik analisis yang akan dilakukan penulis adalah teknik analisis data secara kualitatif, yaitu penelitian yang dilakukan dengan cara melakukan penekanan permasalahan yang diteliti, lebih spesifiknya atau lebih dalamnya data yang telah didapatkan oleh peneliti. Selain itu, dalam penelitian yang bersifat kualitatif ini perspektif atau pandangan subjektif dari peneliti lebih ditonjolkan .

\section{PEMBAHASAN}

A. Keabsahan Penjaminan Hak Milik Atas Tanah yang Didasarkan pada Akta di Bawah Tangan.

Permasalahan pertama yang akan dibahas ialah mengenai keabsahan penjaminan hak milik atas tanah yang didasarkan pada akta di bawah tangan. Awal pula dari permasalahan hukum ini adalah adanya 2 (dua) orang atau pihak yang membuat perjanjian penjaminan hak milik atas tanah di Kabupaten Sragen. Pihak yang pertama ialah Amin Hamidi Hasanudin selaku pemegang objek jaminan atau kreditur dan pihak kedua adalah Suyadi selaku pemberi pemberi objek jaminan atau debitur. Amin Hamidi selaku kreditur dan Suyadi selaku debitur selanjutnya pada tanggal 24 Oktober 2015, menandatangani perjanjian hutang piutang. Pada saat penjaminan hak milik atas tanah tersebut, terdapat halhal yang diperjanjikan oleh para pihak, yaitu :

1. Pihak pertama yaitu Amin Hamidi memberi hutang atau pinjaman uang kepada pihak kedua yaitu Suyadi sebesar Rp200.000.000 (dua ratus juta rupiah).

2. Pihak kedua atau Suyadi sanggup mengembalikan akhir bulan Desember 2015, dengan dengan dua jaminan Sertifikat Hak Milik (SHM) nomor 876 dan Sertifikat Hak Milik (SHM) nomor 877 yang masing-masing atas nama debitur. Apabila akhir bulan Desember 2015 Suyadi belum dapat mengembalikan maka pihak pertama yaitu Amin Hamidi dapat memproses 
secara hukum dan pihak kedua yaitu Sayudi sanggup diproses.

Kreditur selaku pihak pertama telah melaksanakan isi perjanjian atau memberikan hutang sebesar tersebut diatas dalam perjanjian, sedangkan debitur selaku pihak kedua telah menerima hutang tersebut sebesar tersebut yang diatas dan menyerahkan dua jaminan sertifikat tanah atas nama debitur. Namun sampai dengan lewat batas waktu yang telah disepakati dalam perjanjian, debitur tidak mengembalikan hutang tersebut kepada kreditur. Lalu pada tanggal 23 Maret 2017, kreditur telah mengirimkan teguran kepada debitur untuk melaksnakan kewajiban, namun debitur tetap belum menyelesaikan kewajiban membayar hutang kepada kreditur, sehingga debitur disebut wanprestasi terhadap perjanjian yang telah dibuat dan ditandatangani pada tanggal 24 Oktober 2015. Dalam perjanjian tersebut, disepakati jika terjadi wanprestasi atau dalam hal ini debitur tidak melaksanakan kewajiban mengembalikan hutang sampai batas waktu akhir desember 2015, kreditur bisa memproses secara hukum (memproses jaminan) dan debitur sanggup diproses atau dengan kata lain dua jaminan yang berupa tanah sawah yang berdiri diatas sertifikat hak milik atas nama debitur menjadi milik kreditur. Tanah sawah milik debitur yang telah diserahkan sertifikatnya kepada kreditur sebagai jaminan hutang, adalah tersebut dibawah ini :

1. Tanah sawah yang berdiri diatas Sertifikat Hak Milik (SHM) No. 876, terletak di Desa Gawan, Kecamatan Tanon, Kabupaten Sragen, atas nama Suyadi selaku debitur, dengan batas-batas :

a. Sebelah Utara : Jalan.

b. Sebelah Selatan : Sawah Milik Bapak Suyadi.

c. Sebelah Barat : Sawah Milik Bapak Suyadi.

d. Sebelah Timur : Sawah Milik Bapak Suyadi.

2. Tanah sawah yang berdiri diatas Sertifikat Hak Milik (SHM) No. 877, terletak di Desa Gawan, Kecamatan Tanon, Kabupaten Sragen, atas nama 
Suyadi selaku debitur, dengan batas-batas :
a. Sebelah Utara : Jalan.
b. Sebelah Selatan : Sawah Milik Bapak Suyadi.
c. Sebelah Barat : Saluran air / irigasi.
d. Sebelah Timur : Sawah Milik Bapak Suyadi.

Karena debitur telah melakukan wanprestasi, maka sesuai dengan kesepakatan dalam perjanjian tanggal 24 Oktober 2015, debitur harus dihukum menyerahkan obyek jaminan tersebut dan memproses secara hukum obyek jaminan menjadi atas nama kreditur.

Apabila dilihat berdasarkan aturan yang berlaku, sebenarnya penjaminan hak milik atas tanah harus sesuai dengan prosedur yang telah diatur di dalam UndangUndang Nomor 4 Tahun 1996 tentang Hak Tanggungan atas Tanah Beserta Benda-Benda yang Berkaitan Dengan Tanah (UUHT). Dalam menjaminkan Hak atas tanah terdapat perbedaan opini diantara para ahli hukum atau orang-orang yang bergerak di bidang profesi hukum yang berkaitan dengan pertanahan. Menurut data hasil wawancara yang telah dikumpulkan dan dua narasumber ternyata memberikan pendapat yang berbeda. Sumber yang pertama ialah Raden Adrianto S.H yang berprofesi sebagai seorang notaris di daerah Bumi Serpong Damai (BSD), Kota Tangerang Selatan. Menurut pendapat beliau tentang apakah penjaminan hak milik atas tanah yang didasarkan akta di bawah tangan tersebut tetap sah karena tidak dibebankan Hak Tanggungan yang mana merupakan prosedur untuk menjaminkan hak atas tanah tersebut. Menurut pendapat beliau ialah penjaminan hak milik atas tanah tersebut tidak sah atau tidak bisa dilakukan. Apabila yang dijaminkan adalah tanah harus dengan akta autentik yang dibuat oleh PPAT. Sehingga untuk proses eksekusi jaminan HT tersebut agar lebih 
efektif dan mudah. ${ }^{17}$ Lalu menurut narasumber yang kedua yaitu Dr. Tjempaka S.H., M.H., M.Kn. yang juga merupakan seorang notaris yang berdomisili di Kota Bandar Lampung dan juga merupakan Dosen Tetap di Fakultas Hukum Universitas Tarumanagara menyatakan bahwa penjaminan tersebut sah, tetapi akan lebih lama apabila terjadi wanprestasi, karena penjaminan tersebut dilakukan dibawah tangan dan apabila kreditur ingin mengeksekusi akan memakan waktu yang sangat lama. ${ }^{18}$ Narasumber pertama menyatakan bahwa penjaminan tersebut tidak sah karena tidak sesuai prosedur yang telah ditetapkan dalam UUHT dan peraturan peruuan yang mengikutinya, sedangkan narasumber yang kedua menyatakan penjaminan tersebut sah-sah saja, namun akan lama dalam mengeksekusi objek jaminannya karena dilakukan dibawah tangan. Apabila penjaminan hak milik atas tanah tersebut dilakukan tanpa dengan prosedur Hak Tanggungan, makan penjaminannya masuk ke dalam kategori jaminan umum. Menurut Pasal 1131 jo 1132 KUHPerdata jaminan secara umum adalah :

"Segala kebendaan si berutang, baik yang bergerak maupun yang tidak bergerak, baik yang sudah ada maupun yang baru akan ada di kemudian hari, menjadi tanggungan untuk segala perikatan perseorangan."

"Kebendaan tersebut menjadi jaminan bersama-sama bagi semua orang yang mengutangkan padanya, Pendapatan penjualan benda-benda itu dibagi-bagi menurut keseimbangannya, yaitu menurut besar kecilnya piutang masing-masing, kecuali apabila diantara para berpiutang itu ada alasan-alasan yang sah untuk didahulukan.”

Menurut Sri Soedewi Masjchoen Sofwan jaminan secara umum adalah:

“jaminan yang diberikan bagi kepentingan semua kreditur dan menyangkut semua harta kekayaan debitur dan sebagainya. ${ }^{19,}$

\footnotetext{
${ }^{17}$ Peneliti, wawancara, dengan Bapak Raden Adrianto S.H. Notaris dan PPAT yang berdomisili di Bumi Serpong Damai Kota Tangerang Selatan, (Tangerang Selatan : Kantor Notaris dan PPAT Raden Adrianto S.H., 1 Agustus 2018).

18 Peneliti, Wawancara, dengan Ibu Dr.Tjempaka S.H., M.H., M.Kn. Notaris dan PPAT yang berdomisili di Kota Bandar Lampung dan dosen tetap Fakultas Hukum Universitas Tarumanagara, (Jakarta : Perpustakaan Fakultas Hukum Universitas Tarumanagara, 16 Agustus 2018).

19 Sri Soedewi Masjchoen Sofwan, . Hukum Jaminan di Indonesia Pokok-Pokok Hukum Jaminan dan Jaminan Perorangan, Cetakan ke-1. (Yogyakarta: Liberty, 1980), hal. 45.
} 
Artinya benda jaminan tersebut tidak ditunjuk secara khusus dan tidak dimaksudkan untuk dimiliki secara pribadi untuk kreditur, lalu kreditur-kreditur mendapatkan hasil dari penjualan benda-benda yang dijual untuk peluanasan hutang tersebut yang diakibatkan oleh debitur yang cedera janji atau wanprestasi secara seimbang dan jaminan tersebut timbul dari undang-undang. Lalu menurut Munir Fuady jaminan umum adalah:

"jaminan dari pihak debitur yang terjadi by the operation of law dan merupakan mandatory rule, artinya setiap barang bergerak ataupun tidak bergerak milik debitur menjadi tanggungan hutang kepada kreditur. ${ }^{20,}$

Sedangkan menurut Salim HS jaminan umum adalah:

"cara-cara kreditur menjamin dipenuhinya tagihannya, disampingpertanggungan jawab umum debitur terhadap barang barangnya. ${ }^{21,}$

Inti dari teori-teori yang telah dijelaskan diatas ialah jaminan umum merupakan penjaminan yang dilakukan oleh debitur berupa benda-benda baik bergerak maupun tidak bergerak milik debitur kepada kreditur untuk mendapat pinjaman berupa sejumlah uang dan benda yang dijaminkan tersebut berada di tangan kreditur selaku pemegang objek jaminan. Di dalam jaminan umum kedudukan krediturnya ialah kreditur konkuren. Lalu dalam persitiwa hukum dalam rumusan masalah tersebut diatas, selain jaminan umum terdapat apa yang dinamakan perjanjian pinjam meminjam. Menurut Pasal 1754 jo Pasal 1755 KUHPerdata perjanjian pinjam meminjam adalah :

"perjanjian dengan mana pihak yang satu memberikan kepada pihak yang lain suatu jumlah tertentu barang-barang yang menghabis karena pemakaian, dengan syarat bahwa pihak yang belakangan ini akan

\footnotetext{
${ }^{20}$ Munir Fuady, Hukum Jaminan Hutang, Cetakan ke-1. (Jakarta: Erlangga, 2013), hal. 8.

${ }^{21}$ Salim HS, Perkembangan Hukum Jaminan di Indonesia, Cetakan ke-1, (Jakarta: Rajawali Pers, 2004), hal. 21.
} 
mengembalikan sejumlah yang sama dari macam dan keadaan yang sama pula."

"Berdasarkan perjanjian pinjam meminjam ini, pihak yang menerima pinjaman menjadi pemilik barang yang dipinjam, dan jika barang itu musnah, dengan cara bagaimanapun, maka kemusnahan itu adalah atas tanggungannya."

Berdasarkan uraian-uraian tersebut diatas, penjaminan hak milik atas tanah yang didasarkan pada akta di bawah tangan tersebut bisa saja dilakukan. Tanpa dibebankan jaminan khusus berupa Hak Tanggungan penjaminan hak milik atas tanah tersebut dapat dilakukan. Jaminan tersebut masuk dalam kategori jaminan umum. Penjaminan hak milik tersebut apabila dilakukan di bawah tangan akan tidak efektif apabila terjadi wanprestasi yang dilakukan oleh debitur. Apabila penjaminan hak milik atas tanah tersebut dibebankan Hak Tanggungan, jika debitur wanprestasi, maka objek jaminan berupa hak milik atas tanah tersebut dapat langsung dilelang tanpa harus ada putusan pengadilan sebagaimana telah diatur di dalam Pasal 6 Undang-Undang Nomor 4 Tahun 1996 tentang Hak Tanggungan Atas Tanah beserta Benda-Benda yang Berkaitan dengan Tanah sebagai berikut :

“Apabila debitor cidera janji, pemegang Hak Tanggungan pertama mempunyai hak untuk menjual obyek Hak Tanggungan atas kekuasaan sendiri melalui pelelangan umum serta mengambil pelunasan piutangnya dari hasil penjualan tersebut. ${ }^{22,}$

Apabila tidak dibebankan Hak Tanggungan atau hanya berdasarkan akta di bawah tangan, maka apabila debitur wanprestasi, objek jaminan berupa hak milik atas tanah tersebut tidak dapat langsung dilelang, tapi harus mendapatkan penetapan pengadilan terlebih dahulu untuk dilelang Lelang yang dilakukan melalui pengadilan tersebut dinamakan lelang eksekusi. Menurut Pasal 1 Angka 4 Peraturan Menteri Keuangan Republik Indonesia Nomor 27/PMK.06/2016

\footnotetext{
22 Indonesia, Undang-Undang No 4 Tahun 1996 tentang Hak Tanggungan Atas Tanah beserta Benda-Benda yang berkaitan Dengan Tanah (Lembaran Negara Republik Indonesia Tahun 1996 Nomor 42, Tambahan Lembaran Negara Republik Indonesia Nomor 3632), Pasal 6.
} 
tentang Petunjuk Pelaksanaan Lelang, lelang eksekusi adalah :

"Lelang Eksekusi adalah lelang untuk melaksanakan putusan atau penetapan pengadilan, dokumen-dokumen lain yang dipersamakan dengan itu, dan/atau melaksanakan ketentuan dalam peraturan perundang undangan . ${ }^{23}$,

Lelang yang dilakukan dengan dasar putusan atau penetapan yang dikeluarkan oleh pengadilan atau dokumen-dokumen yang statusnya atau jenisnya dipersamakan dengan putusan atau penetapan pengadilan ialah disebut dengan lelang eksekusi. Dokumen-dokumen yang jenisnya atau statusnya sama dengan putusan atau penetapan pengadilan contohnya adalah seperti Hipotek, Hak Tanggungan, atau Jaminan Fidusia. ${ }^{24}$ Jenis atau bentuk lelang inilah yang dimaksud Pasal 200 Ayat (1) Herzien Inlandsch Reglement (HIR) yang bunyinya sebagai berikut :

"Penjualan barang sitaan dilakukan dengan perantaraan kantor lelang atau, menurut pertimbangan ketua atas keadaan, oleh juru sita itu atau orang yang cakap dan dapat dipercaya, ditunjuk oleh ketua dan tinggal di tempat penjualan itu atau di sekitar tempat itu."

Menurut pendapat penulis, dalam hal keabsahan penjaminan hak milik atas tanah tersebut apabila dilakukan dengan akta di bawah tangan keabsahannya kurang mengikat dan kuat pembuktiannya karena perjanjiannya hanya dituangkan di dalam akta di bawah tangan. Karena dalam akta di bawah tangan, pada saat pembuatan akta tersebut tanpa melalui pejabat umum yang berwenang dalam hal ini ialah seorang Pejabat Pembuat Akta Tanah (PPAT), melainkan pembuatan akta tersebut hanya dengan pihak-pihak yang terkait dalam pembuatan akta tersebut. Dalam rumusan masalah yang pertama ini akta yang dibuat oleh para

23 Indonesia, Peraturan Menteri Keuangan Republik Indonesia Nomor 26/PMK.06/2016 tentang Petunjuk Pelaksanaan Lelang (Berita Negara Republik Indonesia Tahun 2016 Nomor 270), Pasal 1 Angka 4.

${ }^{24}$ Sovia Hasanah, "Perbedaan Lelang Eksekusi dengan Lelang Non Eksekusi," https://www.hukumonline.com/klinik/detail/lt5a936ec9770d2/perbedaan-lelang-eksekusi-denganlelang-non-eksekusi, diakses tanggal 16 Oktober 2018. 
pihak hanyalah akta yang dibuat dengan akta di bawah tangan. Isi dalam akta tersebut ialah mengenai peminjam sejumlah uang yang disertai dengan penjaminan berupa 2 (dua) sertifikat hak milik atas tanah. Dalam hal keabsahan penjaminan tersebut apabila dikaitkan dengan teori jaminan umum ialah sah-sah saja menurut hukum. Sebab inti dari jaminan umum adalah suatu benda yang dijaminkan oleh debitur tersebut kepada kreditur dengan maksud untuk mendapat pinjaman berupa sejumlah uang. Namun dalam hal ini yang dijaminkan adalah berupa hak milik atas tanah, dimana apabila yang dijaminkan berupa hak atas tanah jenis penjaminannya ialah jaminan khusus yang diatur didalam UndangUndang Nomor 4 Tahun 1996 tentang Hak Tanggungan Atas Tanah beserta Benda-Benda yang Berkaitan dengan Tanah. Jaminan khusus adalah jaminan yang dapat berupa jaminan kebendaan atau jaminan perorangan. Di dalam jaminan khusus terdapat perjanjian yang secara khusus diadakan oleh kreditur dan debitur untuk menjaminkan sebuah benda yang hendak akan dijadikan jaminan hutang, perjanjian khusus tersebut dapat berupa perjanjian untuk menjaminkan benda tersebut secara jaminan kebendaan atau jaminan perorangan saja. Jaminan kebendaan adalah jaminan yang dilakukan dengan cara adanya benda tertentu yang dijadikan sebagai objek jaminan oleh kreditur dan debitur, sedangkan jaminan perorangan adalah suatu jaminan yang diberikan oleh debitur kepada kreditur berupa janji bahwa debitur akan mampu menebus benda yang dijaminkan tersebut dan membayar hutang-hutang kepada debitur serta memenuhi prestasi yang sudah diperjanjikan dalam perjanjian tersebut. Jaminan kebendaan dalam permasalahan ini ialah seharusnya Hak Tanggungan. Dalam permasalahan ini debitur menjaminkan hak milik atas tanahnya kepada kreditur yang didasarkan hanya akta dibawah tangan dan hanya disepakati oleh kedua belah pihak tanpa adanya saksi. Apabila dilihat dari keabsahannya hal ini sah. Namun dengan adanya UUHT dalam hal penjaminan hak atas tanah disarankan untuk dibebankan Hak Tanggungan. Agar apabila dalam penjaminan Hak Tanggungan tersebut debitur ternyata wanprestasi, kreditur hanya perlu melelang objek jaminan tersebut tanpa harus ada putusan dari pengadilan. 
Jadi jika dikaitkan dengan rumusan masalah yang pertama ini mengenai keabsahan penjaminan hak milik atas tanah yang didasarkan pada akta di bawah tangan ialah, jika merunut pada pasal 1320 KUHPerdata tentang syarat sah perjanjian yang bunyi pasalnya sebagai berikut:

"Supaya terjadi persetujuan yang sah, perlu dipenuhi 4 (empat) syarat :

1. Sepakat.

2. Cakap.

3. Karena suatu hal tertentu.

4. Sebab yang halal.

Jika kita telaah pasal-pasal tersebut dan dikaitkan dengan rumusan masalah yang pertama tentang apakah sah penjaminan hak milik atas tanah ini apabila dilakukan dengan perjanjian yang dituangkan di dalam akta di bawah tangan ialah sah-sah saja. Karena dalam penjaminan tersebut kedua belah pihak yaitu Amin Hamidi selaku kreditur dan Suyadi selaku debitur telah membuat kesepakatan untuk membuat perjanjian dalam jaminan hak milik atas tanah. Yang kedua ialah kedua belah pihak juga sudah cakap dalam melakukan perbuatan hukum sesuai dengan ketentuan pasal 330 KUHPerdata bahwa kedua belah pihak telah berusia diatas 21 tahun dan sudah cakap hukum. Lalu kedua belah pihak juga membuat perjanjian tersebut karena ada suatu hal yang diperjanjikan yaitu perjanjian peminjaman uang yang dibebankan perjanjian penjaminan hak milik atas tanah, yang menimbulkan hak dan kewajiban diantara kedua belah pihak yang membuat perjanjian tersebut. Dan yang terakhir adalah perjanjian yang dibuat oleh kedua belah pihak tersebut tidak dilarang oleh ketentuan hukum yang berlaku.

Berdasarkan uraian-uraian tersebut yang penulis kemukakan, dapat ditarik kesimpulan bahwa penjaminan tersebut sah-sah saja apabila yang dijaminkan hanya dengan akta dibawah tangan, namun apabila debitur wanprestasi akan sulit untuk mengeksekusi objek jaminan tersebut. Kreditur dalam penjaminan ini bukanlah kreditur preferen melainkan kreditur konkuren menurut Pasal 1131 KUHPerdata, kreditur konkuren adalah : 
"Segala barang-barang bergerak dan tak bergerak milik debitur, baik yang sudah ada maupun yang akan ada, menjadi jaminan untuk perikatan-perikatan perorangan

\section{B. Kekuatan Eksekutorial Apabila Penjaminan Hak Milik Atas Tanah Tersebut Didasarkan Pada Akta di Bawah Tangan.}

Pada kasus ini Amin Hamidi selaku kreditur dan Suyadi selaku debitur telah melakukan perjanjian meminjamkan uang sejumlah Rp200.000.000 (dua ratus juta rupiah) dari Amin Hamidi selaku kreditur kepada Suyadi selaku debitur dan dalam perjanjian tersebut terdapat 2 Sertifikat Hak Milik atas tanah yang dijaminkan oleh Suyadi selaku debitur yaitu SHM no. 876 dan SHM no. 877. Dalam perjanjian ini Suyadi selaku debitur wanprestasi dan Amin Hamidi selaku kreditur yang lebih tepatnya selaku kreditur konkuren dalam hal ini ingin agar debitur membayar sejumlah hutangnya. Berikut merupakan putusan akhir Pengadilan Negeri Sragen nomor 53/Pdt.G/2017/PN.Sgn ialah sebagai berikut :

1. Mengabulkan Gugatan Penggugat untuk sebagian ;

2. Menyatakan sah perjanjian Hutang Piutang antara Penggugat dengan Tergugat yang dibuat dan ditandatangani tanggal 24 Oktober 2015 ;

3. Menyatakan dua tanah sawah tersebut dibawah ini :

a. Tanah Sawah yang berdiri diatas Sertifikat Hak Milik (SHM) No. 876, terletak di Desa Gawan, Kecamatan Tanon, Kabupaten Sragen, atas nama Tergugat, dengan batas-batas :

1) Sebelah Utara : Jalan.

2) Sebelah Selatan : sawah milik Bapak Suyadi.

3) Sebelah Barat : sawah milik Bapak Suyadi.

4) Sebelah Timur : sawah milik Bapak Suyadi.

b. Tanah Sawah yang berdiri diatas Sertifikat Hak Milik (SHM) No. 877, terletak di Desa Gawan, Kecamatan 
Tanon, Kabupaten Sragen, atas nama Tergugat, dengan batas-batas :

1) Sebelah Utara : Jalan.

2) Sebelah Selatan : sawah milik Bapak Suyadi.

3) Sebelah Barat : Saluran air/irigasi.

4) Sebelah Timur : sawah milik Bapak Suyadi.

Adalah Obyek Jaminan.

4. Menyatakan Tergugat telah melakukan wanprestasi terhadap perjanjian hutang piutang tertanggal 24 Oktober 2015 ;

5. Menghukum Tergugat untuk membayar biaya perkara yang timbul dalam perkara ini dihitung hingga putusan ini dijatuhkan sebesar Rp658.000,00 (enam ratus lima puluh delapan ribu rupiah) ;

6. Menolak gugatan Penggugat untuk selain dan selebihnya ;

Dalam analisis terhadap rumusan masalah kedua yaitu mengenai eksekutorial objek jaminannya, dalam kasus ini isi dalam perjanjian yang dimuat dalam akta di bawah tangan tersebut di poin kedua dalam perjanjian tersebut ialah apabila debitur wanprestasi, maka debitur sanggup diproses. Yang dimaksud dalam diproses dalam hal ini adalah, karena debitur telah wanprestasi maka sesuai dengan kesepakatan yang dibuat dalam perjanjian yang di muat di dalam akta di bawah tangan tertanggal 24 Oktober 2015, debitur harus dihukum menyerahkan objek jaminan dan memproses secara hukum objek jaminan menjadi atas nama kreditur. Lalu apabila debitur tidak bersedia membantu proses balik nama menjadi atas nama kreditur, maka dengan putusan ini yaitu putusan Pengadilan Negeri Sragen nomor 53/Pdt.G/2017/PN. Sgn dapat dijadikan dasar untuk proses balik nama menjadi atas nama kreditur. Dalam yurisprudensi Putusan Mahkamah Agung tanggal 26-11-1975 No. 883 K/Sip/1974 disebutkan dalam azas hukum perjanjian meminjam barang/uang dengan jaminan barang, melarang untuk menentukan bahwa dalam hal wanprestasi, dari yang berhutang barang jaminan otomatis menjadi milik berpiutang. Maka hal yang dimintakan oleh Amin Hamidi 
selaku kreditur tersebut tidak dapat dilakukan. Lalu jika kita membahas dari sisi Akta dibawah tangan. Dimana akta ini digunakan oleh kedua belah pihak sebagai akta yang mengikat penjaminan hak milik atas tanah tersebut untuk pelunasan hutang. Menurut R.Soeroso akta di bawah tangan adalah :

"akta yang dibuat tidak oleh atau tanpa perantaraan seseorang pejabat umum, melainkan dibuat dan ditandatangani sendiri oleh para pihak yang mengadakan perjanjian, misalnya perjanjian jual beli, sewa menyewa dan pinjam meminjam. ${ }^{25}$,

Menurut pasal 1873 Kitab Undang-Undang Hukum Perdata (KUHPerdata) akta di bawah tangan adalah :

"Persetujuan-persetujuan lebih lanjut, yang dibuat dalam suatu akta tersendiri, yang bertentangan dengan akta asli, hanya memberikan bukti diantara para pihak yang ikut serta, dan para ahli warisnya atau orang-orang yang mendapat hak daripada mereka, tetapi tidak dapat berlaku terhadap orang-orang pihak ketiga."

Dalam rumusan masalah yang kedua ini adalah tentang bagaimana kekuatan eksekutorial apabila penjaminan hak milik atas tanah tersebut didasarkan pada akta di bawah tangan. Pada saat perjanjian penjaminan hak milik atas tanah tersebut, kedua belah pihak yaitu Amin Hamidi selaku penggugat dan Suyadi selaku tergugat hanya dilakukan dengan akta di bawah tangan. Apabila penjaminan tersebut dibebankan dengan Hak Tanggungan, apabila debitur cedera janji pemegang (kreditur) Hak Tanggungan dapat menjual objek hak tanggungan tersebut sebagaimana dijelaskan di dalam Pasal 6 jo Pasal 20 ayat (1) UUPA sebagai berikut :

"Apabila debitur cedera janji, pemegang hak tanggungan pertama mempunyai hak untuk menjual objek hak tanggungan atas kekuasaan sendiri melalui pelelangan umum serta mengambil pelunasan piutangnya dari hasil penjualan tersebut."

“Apabila debitur cedera janji, maka berdasarkan :

a. Hak pemegang Hak Tanggungan pertama untuk menjual obyek Hak Tanggungan sebagaimana

\footnotetext{
${ }^{25}$ R. Soeroso, Perjanjian di Bawah Tangan: Pedoman Praktis Pembuatan dan Aplikasi Hukum, Cetakan ke-2. (Jakarta : Sinar Grafika, 2011), hal. 8.
} 
dimaksud dalam pasal 6, atau

b. Titel eksekutorial yang terdapat di dalam sertifikat Hak Tanggungan sebagaimana dimaksud dalam Pasal 14 ayat (2), obyek Hak Tanggungan dijual melalui pelelangan umum menurut tata cara yang ditentukan dalam peraturan perundang-undangan untuk pelunasan piutang pemegang Hak Tanggungan dengan hak mendahulu daripada kreditur-kreditur lainnya. ${ }^{26,}$

Berdasarkan pasal-pasal tersebut diatas apabila penjaminan hak milik atas tanah tersebut dibebankan Hak Tanggungan, dalam hal debitur cedera janji, pemegang Hak Tanggungan atau kreditur dapat menjual atau melelang objek Hak Tanggungan tersebut sesuai dengan tata cara yang telah diatur di dalam peraturan perundang-undangan.

Namun dalam hal ini, penjaminan yang dilakukan hanya berdasarkan akta di bawah tangan dan yang menjadi pertanyaannya adalah bagaimana cara penjaminan hak milik atas tanah tersebut apabila penjaminannya dilakukan dengan akta di bawah tangan ? Menurut Raden Adrianto S.H seorag notaris yang berkedudukan di BSD kota Tangerang selatan ialah kekuatan eksekutorialnya akan sangat sulit apabila dibuat dengan akta di bawah tangan. Selain sulit eksekusinya akan sangat lama sekali. Yang membuat eksekusinya lama ialah diperlukan putusan pengadilan untuk eksekusi objek jaminannya, dalam hal ini ialah tanah. Lalu jika telah dibebankan HT akan lebih mudah eksekusinya, yaitu apabila debitur wanprestasi dapat langsung dilelang sesuai dengan peraturan perundang-undangan yang berlaku. ${ }^{27}$ Lalu menurut pendapat yang kedua yaitu menurut Dr. Tjempaka S.H., M.H., M.Kn. seorang notaris yang berdomisili di Kota Bandar Lampung dan juga merupakan dosen tetap Fakultas Hukum

\footnotetext{
${ }^{26}$ Indonesia, Undang-Undang No 4 Tahun 1996 tentang Hak Tanggungan Atas Tanah beserta Benda-Benda yang berkaitan Dengan Tanah (Lembaran Negara Republik Indonesia Tahun 1996 Nomor 42, Tambahan Lembaran Negara Republik Indonesia Nomor 3632), Op.Cit., Pasal 6 dan Pasal 20.

${ }^{27}$ Peneliti, wawancara, dengan Bapak Raden Adrianto S.H. Notaris dan PPAT yang berdomisili di Bumi Serpong Damai Kota Tangerang Selatan, (Tangerang Selatan : Kantor Notaris dan PPAT Raden Adrianto S.H., 1 Agustus 2018).
} 
Universitas Tarumanagara adalah apabila penjaminan tersebut dilakukan dengan akta di bawah tangan tanpa dibebankan Hak Tanggungan ialah harus mendapat penetapan dari pengadilan. Intinya apabila dilakukan di bawah tangan, itu akan sangat sulit dan membutuhkan bukti-bukti yang kuat untuk mendapat penetapan pengadilan. $^{28}$

Berdasarkan hal tersebut ialah dapat ditarik jawaban bahwa kekuatan eksekutorial apabila penjaminan tersebut didasarkan pada di bawah tangan dapat terjadi atau dilakukan, namun eksekusi terhadap objek jaminan tersebut yang merupakan tanah yang dibebankan hak milik tersebut akan sulit dilakukan karena untuk dapat mengeksekusi objek jaminan tersebut dibutuhkan penetapan dari pengadilan. Eksekusi objek jaminan yang membutuhkan penetapan dari pengadilan tersebut dinamakan lelang eksekusi. Lelang eksekusi menurut menurut Pasal 1 Angka 4 Peraturan Menteri Keuangan Republik Indonesia Nomor 27/PMK.06/2016 tentang Petunjuk Pelaksanaan Lelang, lelang eksekusi adalah :

"Lelang Eksekusi adalah lelang untuk melaksanakan putusan atau penetapan pengadilan, dokumen-dokumen lain yang dipersamakan dengan itu, dan/atau melaksanakan ketentuan dalam peraturan perundang undangan . ${ }^{29,}$

Jenis atau bentuk lelang inilah yang dimaksud Pasal 200 Ayat (1) Herzien Inlandsch Reglement (HIR) yang bunyinya sebagai berikut :

"Penjualan barang sitaan dilakukan dengan perantaraan kantor lelang atau, menurut pertimbangan ketua atas keadaan, oleh juru sita itu atau orang yang cakap dan dapat dipercaya, ditunjuk oleh ketua dan tinggal di tempat penjualan itu atau di sekitar tempat itu."

\section{PENUTUP}

\section{A. Kesimpulan}

\footnotetext{
${ }^{28}$ Peneliti, Wawancara, dengan Ibu Dr.Tjempaka S.H., M.H., M.Kn. Notaris yang berdomisili di Kota Bandar Lampung dan dosen tetap Fakultas Hukum Universitas Tarumanagara, (Jakarta : Perpustakaan Fakultas Hukum Universitas Tarumanagara, 16 Agustus 2018).

${ }^{29}$ Indonesia, Peraturan Menteri Keuangan Republik Indonesia Nomor 26/PMK.06/2016 tentang Petunjuk Pelaksanaan Lelang (Berita Negara Republik Indonesia Tahun 2016 Nomor 270), Loc.Cit.
} 


\section{Keabsahan Penjaminan Hak Milik Atas Tanah yang Didasarkan pada Akta di Bawah Tangan.}

Kesimpulan yang dapat ditarik dari rumusan masalah yang pertama ini yaitu mengenai keabsahan penjaminan hak milik atas tanah yang didasarkan pada akta di bawah tangan ini, jika dilihat dari apa yang dibahas sebelumnya dan berdasarkan data-data yang telah dikumpulkan adalah bahwa penjaminan tersebut sah-sah sajadapat saja dilakukan, asalkan perjanjian utama dari penjaminan tersebut tidak bertentangan dengan ketentuan yang diatur di dalam Pasal 1320 KUHPerdata mengenai syarat sah perjanjian yaitu sepakat, cakap, suatu hal tertentu dan sebab yang halal.

\section{Kekuatan Eksekutorial Apabila Penjaminan Hak Milik Atas Tanah Tersebut} Didasarkan pada Akta di Bawah Tangan.

Dalam penjaminan ini jenis jaminan yang digunakan ialah jaminan umum, dimana Suyadi selaku debitur menjaminkan 2 (dua) sertifikat tanah miliknya yaitu sertifikat hak milik atas tanah nomor 876 dan nomor 877 kepada Amin Hamidi selaku kreditur untuk pelunasan hutangnya yang sebesar Rp200.000.000 (dua ratus juta rupiah). Kekuatan eksekutorialnya apabila penjaminan tersebut hanyalah bersifat jaminan umum akan lumayan sulit dan cukup lama, karena untuk mengeksekusi objek jaminan tersebut harus ditetapkan lelang eksekusi terlebih dahulu oleh Pengadilan sesuai dengan ketentuan di dalam Pasal 200 HIR. Namun apabila penjaminan tersebut dibebankan jaminan khusus atau dalam hal ini ialah hak tanggungan, maka apabila Suyadi selaku debitur wanprestasi, eksekusi objek hak tanggungannya tersebut akan sangat mudah, hanya tinggal dilelang secara umum sesuai ketentuan Pasal 6 jo Pasal 20 UUHT.

\section{B. Saran}

1. Sebaiknya kreditur dan debitur dalam membuat perjanjian pinjam meminjam yang dibebankan penjaminan hak milik atas tanah disarankan agar dibuat dihadapan pejabat umum yang berwenang dalam hal ini ialah PPAT berupa Akta Pembebanan Hak Tanggungan (APHT). Setelah pembuatan APHT harus diikuti dengan pendaftaran Hak Tanggungan di Badan Pertanahan Nasional 
(BPN). Agar pembuktiannya kuat dan penyelesaiannya lebih mudah apabila debitur mengalami wanprestasi.

2. Mengenai kekuatan eksekutorialnya karena dalam kasus ini jaminannya hanya jaminan umum, maka eksekusinya akan lebih sulit karena dibutuhkan penetapan dari pengadilan untuk melelang objek jaminannya tersebut. Saran dari penulis ialah apabila menjaminkan hak atas tanah dalam suatu perjanjian, baiknya dibebankan hak tanggungan agar eksekusinya lebih mudah dan tidak memakan waktu yang cukup lama.

\section{DAFTAR PUSTAKA}

\section{A. Buku}

Diantha, I Made Pasek. Metodologi Penelitian Hukum dalam Justifikasi Teori Hukum. Cetakan ke-1. (Jakarta: Prenada, 2016).

ELIPS. Seri Dasar Hukum Ekonomi 4 : Hukum Jaminan Indonesia. Cetakan ke-1. (Jakarta: Proyek ELIPS, 1998).

Fajar, Mukti. dan Yulianto Achmad. Dualisme Penelitian Hukum Normatif dan Empiris. Cetakan ke-1. (Yogyakarta: Pustaka Pelajar, 2010).

Fuady, Munir. Hukum Jaminan Hutang. Cetakan ke-1. (Jakarta: Erlangga, 2013).

Harsono, Boedhi. Hukum Agraria Indonesia Sejarah Pembentukan UndangUndang Pokok Agraria, Isi dan Pelaksanaannya. Cetakan ke-9. (Jakarta: Djambatan, 2003).

Sahnan. Hukum Agraria Indonesia. Cetakan ke-1. (Malang: Setara, 2016).

Soeroso, R. Perjanjian di Bawah Tangan : Pedoman Praktis Pembuatan dan Aplikasi Hukum. Cetakan ke-2. (Jakarta : Sinar Grafika, 2011).

Soekanto, Soerjono. Penelitian Hukum Normatif Suatu Tinjauan Singkat. Cetakan ke-7. (Jakarta: Persada, 2003).

Sofwan, Sri Soedewi Maschjoen. Hukum Jaminan di Indonesia Pokok-Pokok Hukum Jaminan dan Jaminan Perorangan. Cetakan ke-1. (Yogyakarta: Liberty, 1980).

Widjaja, Gunawan. dan Kartini Muljadi. Seri Hukum Harta Kekayaan Hak Tanggungan. Cetakan ke-2. (Jakarta: Prenada, 2006). 


\section{B. Undang-Undang}

Indonesia. Kitab Undang-Undang Hukum Perdata.

. Kitab Undang-Undang Hukum Acara Perdata (Herzien Inlandsch Reglement)

. Undang-Undang Dasar Negara Republik Indonesia tahun 1945.

. Undang-Undang Nomor 5 Tahun 1960 tentang Peraturan Dasar Pokok-Pokok Agraria (Lembaran Negara Republik Indonesia Tahun 1960 Nomor 104, Tambahan Lembaran Negara Republik Indonesia Nomor 2043).

. Undang-Undang Nomor 4 Tahun 1996 tentang Hak Tanggungan atas Tanah Beserta Benda-Benda yang Berkaitan dengan Tanah (Lembaran Negara Republik Indonesia Tahun $1996 \quad$ Nomor 42, Tambahan Lembaran Negara Republik Indonesia Nomor 3632).

Peraturan Menteri Keuangan Republik Indonesia Nomor 26/PMK.06/2016 tentang Petunjuk Pelaksanaan Lelang (Berita Negara Republik Indonesia Tahun 2016 Nomor 270).

\section{Kamus}

Departemen Pendidikan dan Kebudayaan. Kamus Besar Bahasa Indonesia.

(Jakarta : Balai Pustaka, 1988).

\section{Wawancara}

Adrianto, Raden. Wawancara dengan penulis. Kantor Notaris dan Pejabat Pembuat Akta Tanah (PPAT) Raden Adrianto S.H. Plaza Cordoba D5, Sektor VIX. 4, Nusaloka, Bumi Serpong Damai, Kota Tangerang Selatan. Tangerang Selatan, 1 Agustus 2018.

Tjempaka. Wawancara dengan penulis. perpustakaan Fakultas Hukum Universitas Tarumanagara. Jakarta, 16 Agustus 2018.

\section{E. Website}


Hasanah, Sovia. "Perbedaan Lelang Eksekusi dengan Lelang Non Eksekusi." https://www.hukumonline.com/klinik/detail/lt5a936ec9770d2/per edaan-lelang-eksekusi-dengan-lelang-non-eksekusi.Diakses tanggal 16 Oktober 2018. 

Keabsahan Penjaminan Hak Milik Atas Tanah Yang Didasarkan Pada Akta Di Bawah Tangan (Studi Kasus Putusan Nomor 53/Pdt.G/2017/PN.Sgn) 